\title{
Cycloheximide Resistant Incorporation of Amino Acids into a Polypeptide of the Cytochrome Oxidase of Neurospora crassa
}

\author{
Hanns Weiss, Walter Sebald, and Theodor Bücher \\ Institut für Physiologische Chemie und Physikalische Biochemie der Universität München
}

(Received May 5/June 23, 1971)

\begin{abstract}
Radioactive leucine was incorporated by Neurospora crassa mitochondria in vivo in the presence of cycloheximide. When the membrane protein of these mitochondria was chromatographically separated on oleyl polymethacrylic acid resin, a number of fractions were obtained which differ with respect to their contents of radioactivity and cytochromes. The highest specific radioactivity was found in the fraction containing cytochrome $a a_{3}$. This fraction proved to be a pure and enzymatically active cytochrome oxidase. Its ratio of absorbance at $280 \mathrm{~nm}$ (ox)/ $443 \mathrm{~nm}$ (red.) was 2.1. By means of sodium dodecylsulfate gel-electrophoresis, this enzyme was separated into five polypeptides with molecular weights of $30000,20000,13000,10000$, and 8000 . Only the polypeptide with the molecular weight 20000 displayed a high specific radioactivity.
\end{abstract}

It is well known today, that mitochondria possess their own protein synthesizing system [1-3], responsible for the synthesis of part of the proteins of the inner mitochondrial membrane [4-6]. This system was shown to be insensitive to cycloheximide [7-10], an effective inhibitor of the cytosolic protein synthesis [11]. In the presence of this inhibitor the proteins synthesized inside the mitochondria could be specifically labeled by the incorporation of radioactive amino acids [9]. However, our knowledge about function, size and composition of the products of the mitochondrial protein synthesis is still very limited. This probably is due to the difficulty of their separation and purification.

The recently described polyacrylic acid resin, of which carboxylic groups were partially linked with oleylamine by amide bonds, is particularly appropriate for the chromatographic separation of mem. brane protein [12]. In this study such a resin was applied to the separation of membrane proteins of Neurospora crassa mitochondria, into which radioactive amino acids had been incorporated in vivo in the presence of cycloheximide.

\section{METHODS}

Preparation of the Radioactively Labeled Mitochondrial Membrane Protein

Neurospora crassa, wild type 74 A, was cultured as described [13]. For labeling of the total hyphae protein $0.15 \mathrm{mCi} \mathrm{L}-\left[{ }^{14} \mathrm{C}\right]$ leucine was added to a $4 \mathrm{l}$

Enzyme. Cytochrome oxidase or ferrocytochrome $c: \mathrm{O}_{\mathrm{g}}$ oxidoreductase (EC 1.9.3.1). culture of $18 \mathrm{~h}$ grown hyphae (approximately $2.5 \mathrm{~g}$ protein) and the culture was allowed to grow for an additional $30 \mathrm{~min}$. Then cycloheximide was added (0.1 mg/ml) (Carl Roth OHG, Karlsruhe, Germany). After $4 \mathrm{~min}$ of vigorous shaking $1.0 \mathrm{mCi} \mathrm{L}\left[{ }^{3} \mathrm{H}\right]$ leucine was added. After $30 \mathrm{~min}$ the labeling was chased by the addition of unlabeled DL-leucine (1 $\mathrm{mM}$ ) and $30 \mathrm{~min}$ later the hyphae were harvested. The washed cells were disrupted with a grind mill and mitochondria were isolated as described [13]. Mitochondria were sonicated in $0.1 \mathrm{M}$ potassium phosphate buffer $\mathrm{pH} 8.0$ and membrane protein was separated from matrix protein by high speed centrifugation [12].

\section{Chromatography on Oleyl Polymethacrylic Acid Resin}

The procedure for the preparation of the oleyl polymethacrylic acid resin and for the chromato. graphic separation of the membrane protein as described earlier [12], was modified as follows. Polymethacrylic acid resin (Amberlite, CG 50 III, Serva Entwicklungslabor, Heidelberg, Germany) was used as commencing resin instead of polyacrylic acid resin.

The elementary analysis and the cation exchange capacity of the resins used in this work are summarized in Table 1.

$30 \mathrm{mg}$ membrane protein was separated on $6 \mathrm{~g}$ resin (wet weight). The column $(16 \times 0.8 \mathrm{~cm})$ was equilibrated with $0.1 \mathrm{M}$ Tris-acetate buffer, $\mathrm{pH}$ 6.0, before applying the solubilized protein. The proteins were eluted at a rate of $10 \mathrm{ml} / \mathrm{h}$ with the series of gradients summarized in Table 2 . The temperature was kept at $2^{\circ} \mathrm{C}$. 
The fractions with the highest content of cytochrome $a a_{3}$ (gradient VIII) were combined $(26 \mathrm{ml}$ ) and desalted by gel filtration on a column $(85 \times 2.5 \mathrm{~cm})$ of Sephadex G-25 (Pharmacia, Uppsala, Sweden), which had been equilibrated with $0.05 \mathrm{M}$ Tris-acetate buffer, $\mathrm{pH}$ 8.0.

In order to remove excess Tween 80 , to concentrate and to further purify the enzyme, the desalted solution of cytochrome $a a_{3}(50 \mathrm{ml})$ was applied to a small column $(1.0 \times 0.8 \mathrm{~cm})$ of DEAE-cellulose (Serva Entwicklungslabor, Heidelberg, Germany) equilibrated with $0.05 \mathrm{M}$ Tris-acetate, $\mathrm{pH}$ 8.0.

After washing the column with $0.05 \mathrm{M}$ Trisacetate, $\mathrm{pH} 8.0(20 \mathrm{ml})$, cytochrome $a a_{3}$ was eluted

Table 1. Elementary analysis and cation exchange capacity of the polymethacrylic acid and of the oleyl polymethacrylic acid resin

Elementary analysis were generously performed in the laboratory of E. Wünsch (Max-Planck-Institut für EiweiB- und Lederforschung, München). Cation exchange capacities were evaluated from titration curves performed with an automatic titrator (Radiometer Copenhagen, Denmark) over a period of $24-35 \mathrm{~h}$

\begin{tabular}{|c|c|c|c|c|}
\hline \multirow{2}{*}{ Resin } & \multicolumn{3}{|c|}{ Elementary analysis } & \multirow{2}{*}{$\begin{array}{c}\text { Cation } \\
\text { exchange } \\
\text { capacity }\end{array}$} \\
\hline & c & H & $\mathbf{N}$ & \\
\hline & $\%$ & $\%$ & $\%$ & $\begin{array}{c}\text { mequiv./g } \\
\text { dry } w^{2} t\end{array}$ \\
\hline Polymethacrylic acid & 54.8 & 7.0 & - & 10.1 \\
\hline $\begin{array}{l}\text { Oleyl polymethacrylio } \\
\text { acid }\end{array}$ & 66.3 & 9.6 & 2.2 & 3.6 \\
\hline
\end{tabular}

with a solution of $0.3 \mathrm{M} \mathrm{KCl}$ and $0.05 \mathrm{M}$ Tris-acetate, $\mathrm{pH} 8.0(1.5 \mathrm{ml})$. While cytochrome $a a_{3}$ was added to and washed on the column the flow rate was $50 \mathrm{ml} / \mathrm{h}$. The cytochrome $a a_{3}$ was eluted with a flow rate of $10 \mathrm{ml} / \mathrm{h}$.

\section{Sodium Dodecylsulfate Gel Electrophoresis}

The solution of cytochrome $a a_{3}$ was dialysed against water $(10-20 \mathrm{~b})$ and lyophilized. The protein pellet was dissolved in $5 \%$ sodium dodecylsulfate, $5 \%$ mercaptoethanol and $0.1 \mathrm{M}$ Tris-Cl, $\mathrm{pH} 8.0$, $(10 \mathrm{mg}$ protein $/ \mathrm{ml})$ by incubation at $37^{\circ} \mathrm{C}$ for $4 \mathrm{~h}$. Total membrane protein was dissolved directly in the same medium.

Polyacrylamide gels $(\mathbf{1 0} \%)$ were polymerized from two stock solutions containing (a) $8 \mathrm{~g}$ acrylamide, $0.215 \mathrm{~g} N, N^{\prime}$-methylene bisacrylamide, $0.1 \mathrm{ml}$ $N, N, N^{\prime}, N^{\prime}$-tetramethyl ethylenediamine, and water to $60 \mathrm{ml}$; (b) $0.1 \mathrm{~g}$ ammonium peroxodisulfate and water to $20 \mathrm{ml}$. The two stock solutions were mixed at a ratio $3: 1$ and allowed to polymerize in horizontal molds, $0.2 \times 5 \times 15 \mathrm{~cm}$. The gels were equilibrated for 2 days with a solution of $0.5 \%$ sodium dodecylsulfate, $0.1 \mathrm{M}$ Tris- $\mathrm{Cl}, \mathrm{pH} 8.0$ and $0.05 \mathrm{M}$ mercaptoethanol and stored in the same solution. Before electrophoresis, the gels were carefully freed from adherent liquid betwen two layers of filter paper and then placed on a sheet of glass. A $1 \mathrm{~cm}$ long slit was cut in the gel by means of a razor-blade. This slit was slightly spread (about $0.5 \mathrm{~mm}$ ) and filled with $0.01 \mathrm{ml}$ of the protein solution. The gel was brought

Table 2. Buffer, salt and detergent concentrations of the gradient components

For preparing gradients II and $V$ three equal vessels were connected in series by means of two U-tubes. The contents of the first and second vessel of each series were stirred. The elution solution was taken from the first vessel by a LKB-Perpex pump (LKB, Stockholm, Sweden). Gradient IV was prepared by means of a series of two equal vessels

\begin{tabular}{|c|c|c|c|c|c|c|}
\hline $\begin{array}{c}\text { Gradient } \\
\text { no. }\end{array}$ & $\begin{array}{l}\text { Vessel } \\
\text { no. }\end{array}$ & Volume & $\begin{array}{c}\text { Tris acetate } \\
\text { pH } 8.0\end{array}$ & $\begin{array}{c}\text { Potassium } \\
\text { cholate + deoxycholate } \\
(1: 1) \mathrm{pH} 8.0 \\
\end{array}$ & $\mathbf{K C l}$ & Tween 80 \\
\hline & & $\mathrm{ml}$ & $\mathbf{M}$ & $\%$ & $\mathbf{M}$ & $\%$ \\
\hline I & - & 40 & $0.1(\mathrm{pH} 6.0)$ & & & \\
\hline \multirow[t]{3}{*}{ II } & 1 & 15 & 0.10 & & & \\
\hline & 2 & 15 & 1.00 & & & \\
\hline & 3 & 15 & 0.01 & & & \\
\hline III & - & 35 & 0.01 & & & \\
\hline \multirow[t]{2}{*}{ IV } & 1 & 40 & 0.01 & & & \\
\hline & 2 & 40 & 0.01 & 1 & & \\
\hline \multirow[t]{3}{*}{ V } & 1 & 40 & 0.01 & 1 & & \\
\hline & 2 & 40 & 0.20 & 1 & & \\
\hline & 3 & 40 & 0.20 & 1 & 2 & \\
\hline VI & - & 130 & 0.20 & 1 & 2 & \\
\hline VII & - & 25 & 0.20 & - & 3 & \\
\hline VIII & - & 50 & 0.20 & - & 3 & 0.5 \\
\hline
\end{tabular}


in contact with the electrode buffer $(0.5 \%$ sodium dodecylsulfate, $0.1 \mathrm{M}$ Tris-Cl, $\mathrm{pH}$ 8.0) with thick filter paper. To prevent drying out the gel was covered with a piece of polyethylene foil ; $20 \mathrm{~mA}$ were applied to the gel. The electrophoresis was stopped when a sample of cytochrome $c$ (Boehringer, Mannheim $\mathrm{GmbH}$, Mannheim, Germany) applied in an additional small slit had migrated exactly $6 \mathrm{~cm}$ (about $4 \mathrm{~h}$ ). For staining of the proteins, the gel was incubated with $5 \%$ coomassie brilliant blue R-250 (Serva Entwicklungslabor, Heidelberg, Germany) in methanolwater-acetic acid $(5: 5: 1, \nabla / v / v)$ for $2 \mathrm{~h}$. The gel was destained in this solvent for $24 \mathrm{~h}$ and finally stored in $10 \%$ acetic acid. For determination of radioactivity, the unstained gel was cut in small slices. The slices were shaken with $0.5 \mathrm{ml} 0.5 \%$ sodium dodecylsulfate, $0.1 \mathrm{M}$ Tris-Cl, $\mathrm{pH} 8.0$, in counting vials at $60{ }^{\circ} \mathrm{C}$ for $4-5 \mathrm{~h}$. Radioactivity was counted as described below.

\section{Assay of Cytochrome Oxidase Activity}

Cytochrome oxidase activity was measured spectrophotometrically at $25^{\circ} \mathrm{C}$ by following the decrease of absorbance at $550 \mathrm{~nm}$ of ferrocytochrome $c(50 \mu \mathrm{M})$ in 0.1 M Tris-acetate buffer $\mathrm{pH} 8.0$ [14].

\section{Determination of Cytochrome Contents}

Cytochrome contents were determined from difference spectra (reduced minus oxidized) performed with a split beam spectrophotometer designed by M. Klingenberg or with a Beckman DK 1A Recording Spectrophotometer, using the following molar absorption coefficients: for cytochrome $a a_{3} \Delta \varepsilon_{605 \mathrm{~nm}}=$ $24 \times 10^{3} \mathrm{M}^{-1} \mathrm{~cm}^{-1}$ [15] and for cytochrome $b \Delta \varepsilon_{561} \mathrm{~nm}$ $=16 \times 10^{3} \mathrm{M}^{-1} \mathrm{~cm}^{-1}[16]$.

\section{Protein Determination}

Protein was determined with the biuret method [17].

\section{Determination of Radioactivity}

Two equal portions of each cell fraction (Table 3) were washed three times with $5 \%$ trichloroacetic acid and twice with acetone and were allowed to dry. One portion was used for protein determination. The other one was solubilized with $1 \%$ sodium dodecylsulfate (approximately $0.1 \mathrm{mg} / \mathrm{ml}$ ) by sonication. $0.1 \mathrm{ml}$ of this protein solution was added to $15 \mathrm{ml}$ scintillation liquid $(6 \mathrm{~g}$ butyl PBD, CIBA, Basel, Switzerland, in $600 \mathrm{ml}$ toluene and $400 \mathrm{ml}$ ethylene glycol monomethylether). Radioactivity was measured with a scintillation counter (Packard, Illinois, U.S.A.).

\section{RESULTS}

Effect of Cycloheximide on Incorporation of Leucine into the Proteins of Various Cell Fractions

In a first labeling period, $\left[{ }^{14} \mathrm{C}\right] l$ leucine was incorporated into total cell protein. Added cycloheximide then stopped the cytosolic protein synthesis. Thus, in the second labeling period, $\left[{ }^{3} \mathrm{H}\right]$ leucine was incorporated only into that part of mitochondrial membrane protein, which is synthesized by the mitochondrial ribosomes.

The contents of ${ }^{14} \mathrm{C}$ and ${ }^{3} \mathrm{H}$ radioactivity of the total cell, soluble cytosolic, mitochondrial matrix and mitochondrial membrane protein are summarized in Table 3. While $\left.{ }^{[14} \mathrm{C}\right]$ leucine is distributed fairly equally among the different protein fractions, the specific $\left[{ }^{3} \mathrm{H}\right]$ leucine content of the mitochondrial membrane protein greatly exceeds the values of the other cell proteins.

Table 3. Distribution of [" Clleucine, incorporated before the addition of cycloheximide, and of $\left[^{3} \mathrm{H}\right]$ leucine, incorporated in the presence of cycloheximide

\begin{tabular}{|c|c|c|c|}
\hline \multirow{2}{*}{ Cell fraction } & \multicolumn{2}{|c|}{ Radioactivity } & \multirow{2}{*}{${ }^{3} \mathrm{H} /{ }^{1{ }^{\prime C} \mathrm{C}}$} \\
\hline & ${ }^{s a} \mathrm{C}$ & 'H & \\
\hline & \multicolumn{2}{|c|}{ 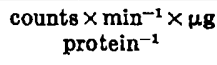 } & \\
\hline Total cell & 87 & 7.0 & 0.08 \\
\hline $\begin{array}{l}100000 \times g \text { supernatant of } \\
\text { cytosol }\end{array}$ & 94 & 1.9 & 0.02 \\
\hline Mitochondrial matrix & 68 & 7.5 & 0.09 \\
\hline Mitochondrial membrane & 59 & 44 & 0.73 \\
\hline
\end{tabular}

\section{Chromatographic Separation of the Labeled Mitochondrial Membrane Protein on Oleyl Polymethacrylic Acid Resin}

The result of the chromatographic separation of the labeled mitochondrial membrane protein is shown in Fig. 1. The profile of ${ }^{14} \mathrm{C}$ radioactivity represents total membrane protein, the profile of ${ }^{3} \mathrm{H}$ radioactivity represents those proteins or peptides which were synthesized by the cycloheximide insensitive system. The other curves show the absolute contents of cytochrome $a a_{3}$ and $b$ and the ${ }^{3} \mathrm{H} /{ }^{14} \mathrm{C}$ ratio. The efficiency of separation may be looked upon in terms of the number of protein peaks (Fig. $1 \mathrm{~A}$ ), the appearance of cytochromes (Fig. $1 \mathrm{~B}$ ), and the differences of the ${ }^{3} \mathrm{H} /{ }^{14} \mathrm{C}$ ratios of the protein peaks (Fig. 1B). These ratios may be compared with the corresponding ratio of the total membrane protein, also given in Fig. $1 \mathrm{C}$ as a straight horizontal line.

It is remarkable that the ${ }^{3} \mathrm{H} /{ }^{14} \mathrm{C}$ ratio of all fractions eluted from the column, is smaller than the value of the unfractionated membrane protein or 
only equal to it. This is also manifested by the yields of recovery, which amount to approximately $50 \%$ for ${ }^{14} \mathrm{C}$, but only $25 \%$ for ${ }^{3} \mathrm{H}$ radioactivity.

The highest ${ }^{8} \mathrm{H} /{ }^{14} \mathrm{C}$ ratio coincides with the appearance of cytochrome $a a_{3}$. The high value of the first fraction which passes the column without being bound, may be attributed to unincorporated $\left[{ }^{3} \mathrm{H}\right]$ leucine.



Fig.1. Elution profiles of the chromatography of labeled mitochondrial membrane protein on oleyl polymethacrylic acid resin. (A) Profiles of the ${ }^{14} \mathrm{C}$ and ${ }^{3} \mathrm{H}$ radioactivity; (B) profiles of cytochrome $a a_{3}$ and $b$; (C) ${ }^{3} \mathrm{H} /{ }^{14} \mathrm{C}$ ratios. -1 radioactivity; $\mathrm{O}_{-}-\mathrm{O},{ }^{3} \mathrm{H}$ radioactivity; $\triangle-\Delta$, cytochrome $a a_{3} ; 0-0$, cytochrome $b ; \bullet^{3} \mathrm{H} /{ }^{14} \mathrm{C}$ ratio. Roman numerals indicate the gradients, see Table 2

\section{${ }^{3} \mathrm{H}$ Label, Heme aa ${ }_{3}$ Content and Enzymatic Activity of the Cytochrome Oxidase}

Table 4 presents data of radioactive label, heme $a a_{3}$ content, enzymatic activity, and yield of cytochrome oxidase.

The final preparation proved to represent cytochrome oxidase of high purity and enzymatic activity Its heme $a a_{3}$ content exceeded the value of the unfractionated membrane 16-fold and its specific activity 14-fold. This cytochrome oxidase contains also a remarkable amount of cycloheximide insensitive $\left[{ }^{3} \mathrm{H}\right]$ leucine label.

The absolute spectra of the oxidized and dithionite reduced form of a typical preparation are shown in Fig. 2. The wavelengths of and the absorbances at the maxima are summarized in Table 5. From these data the ratios of absorbance at $280 \mathrm{~nm}$ (ox.)/443 nm (red.) and at $443 \mathrm{~nm}$ (red.)/428 nm (ox.) are 2.1 and 1.35, respectively. These values fulfil the criteria for purity for crystalline cytochrome oxidase from beaf heart mitochondria [18]. Remarkably the maximum of the oxidized form in the $\gamma$ region is at $428 \mathrm{~nm}$ in contrast to $423 \mathrm{~nm}$ as reported for the cytochrome oxidase isolated from beaf heart or yeast mitochondria $[18,19]$. The other maxima (at $605 \mathrm{~nm}$ and $443 \mathrm{~nm}$ ) show no differences in wavelength for beaf heart, yeast or Neurospora crassa.

\section{Sodium Dodecylsulfate Gel Electrophoresis of the Cytochrome Oxidase}

For analysis of the protein part of the cytochrome oxidase the enzyme was submitted to sodium dodecylsulfate electrophoresis. For comparison, the electrophoresis was performed also with the unfractionated mitochondrial membrane protein. The density of the absorbance of the stained gels at $546 \mathrm{~nm}$, the distribution of the ${ }^{14} \mathrm{C}$ and ${ }^{3} \mathrm{H}$ radioactivity and the ${ }^{3} \mathrm{H} /{ }^{14} \mathrm{C}$ ratio are represented in Fig. 3 and 4.

The method used separates the polypeptides according to their molecular weights [20]. The molecular weight scale used in the abscissae of Fig. 3 and 4

Table 4. Yield of preparation, content of radioactivity, heme a $a_{3}$ content, and enzymatic activity of the cytochrome oxidase

\begin{tabular}{|c|c|c|c|c|c|c|c|c|}
\hline \multirow{2}{*}{ Preparation } & \multirow{2}{*}{ volumo } & \multirow{2}{*}{ Protein } & \multicolumn{2}{|c|}{$10^{-8} \times$ Radioactivity } & \multirow{2}{*}{${ }^{\mathrm{H}} \mathrm{H} /{ }^{3 \cdot \mathrm{C}}$} & \multicolumn{2}{|c|}{ Heme $\alpha a_{2}$} & \multirow{2}{*}{$\begin{array}{l}\text { Enzymatic } \\
\text { activity }\end{array}$} \\
\hline & & & ${ }^{16} \mathrm{C}$ & 'H $\mathrm{H}$ & & Total & Specific & \\
\hline & $\mathrm{ml}$ & $\mathrm{mg}$ & \multicolumn{2}{|c|}{ counts!min } & & nmoles & $\begin{array}{c}\text { nmoles } / \mathrm{mg} \\
\text { protein }\end{array}$ & $\begin{array}{c}\mu \text { moles } \\
\times \min ^{-2} \times \mathrm{mg}^{-3}\end{array}$ \\
\hline Mitochondrial membrane & 1.2 & 30 & 1750 & 1320 & 0.73 & 9.3 & 0.31 & 0.4 \\
\hline $\begin{array}{l}\text { Cytochrome oxidase (from oleyl poly- } \\
\text { methacrylic acid resin) }\end{array}$ & 26 & 0.83 & 49 & 36 & 0.74 & 2.5 & 3.0 & 5.6 \\
\hline $\begin{array}{l}\text { Cytochrome oxidase (from DEAE- } \\
\text { cellulose) }\end{array}$ & 1.4 & 0.23 & 13 & 10 & 0.76 & 1.1 & 4.8 & $\begin{array}{l}1.9 \\
4.6^{\mathrm{a}}\end{array}$ \\
\hline
\end{tabular}

- The enzymatic activity of the cytochrome oxidase eluted from the DEAE-cellulose was determined also in the presence of added Tween 80 , final concentration $0.5 \%$. 


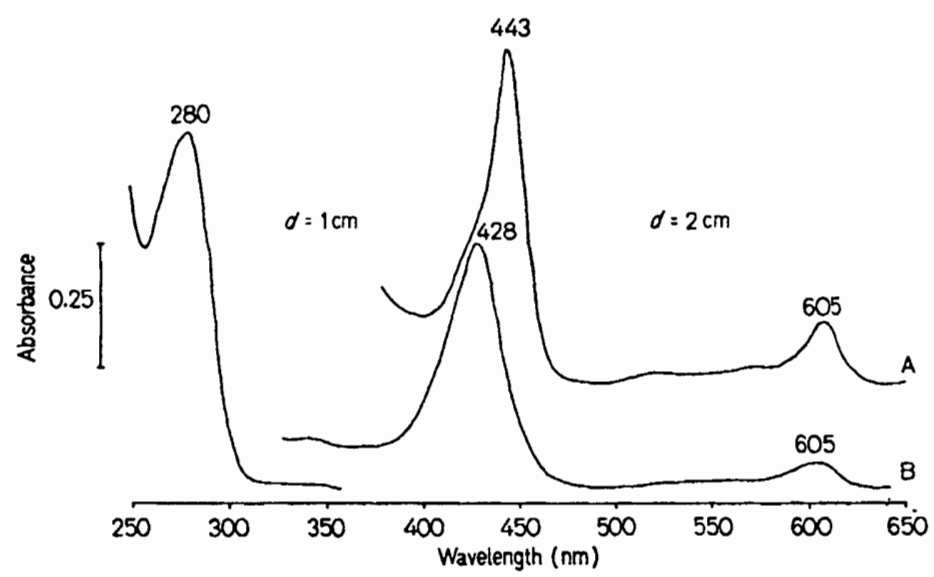

Fig.2. Absolute spectra of the purified cylochrome oxidase of Neurospora crassa. (A) The oxidized (air) form of the cytochrome oxidase; (B) $10 \mathrm{~min}$ after the addition of dithionite

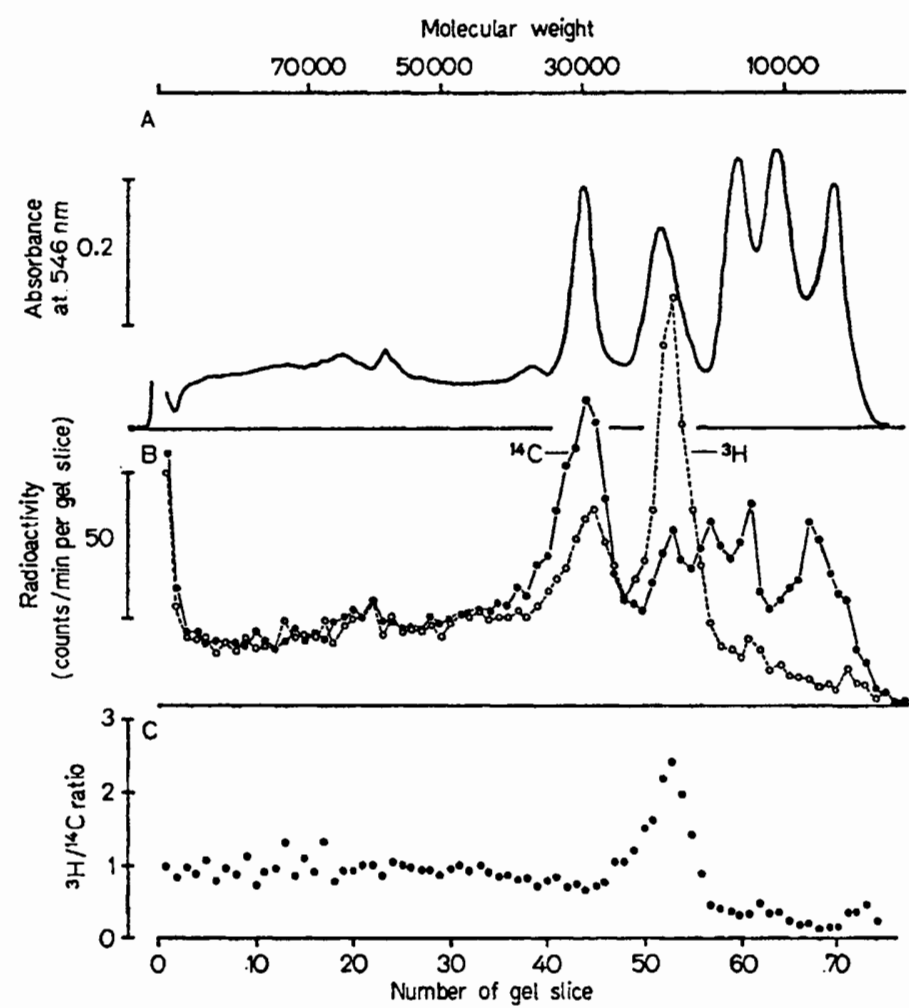

Fig. 3. Electropherogram of the purified cytochrome oxidase. (A) Absorbance of the coomassie brilliant blue stained protein bands; (B) ${ }^{14} \mathrm{C}$ and ${ }^{3} \mathrm{H}$ radioactivity in the gel slices; (C) ${ }^{3} \mathrm{H} /{ }^{4} \mathrm{C}$ ratios. - , absorbance at $546 \mathrm{~nm} ; 0^{-0}{ }^{14} \mathrm{C}$ radioactivity; $\mathrm{O}---\mathrm{O},{ }^{3} \mathrm{H}$ radioactivity; $\bullet,{ }^{3} \mathrm{H} /{ }^{14} \mathrm{C}$ ratio

is calibrated by means of proteins of known molecular weigts (albumin, enolase, triosephosphate isomerase, lactalbumin and cytochrome $c$ ).

After electrophoretic separation of the cytochrome oxidase, 5 protein bands are revealed by coomassie brilliant blue staining as well as by ${ }^{14} \mathrm{C}$ radioactivity (Fig.3). Their molecular weights are estimated to be approximately $30000,20000,13000$, 10000 , and 8000 . Thus, the protein part of the cytochrome oxidase preparation consists of five relatively small polypeptides. The polypeptide with the molecular weight 20000 contains an outstandingly high 




Fig.4. Electropherogram of the mitochondrial membrane protein. (A) Absorbance of the coomassie-brilliant blue stained protein bands; (B) ${ }^{14} \mathrm{C}$ and ${ }^{3} \mathrm{H}$ radioactivity in the gel slices; (C) the ${ }^{3} \mathrm{H} /{ }^{14} \mathrm{C}$ ratios. - , absorbance at $546 \mathrm{~nm}$; $\bullet-\bullet,{ }^{14} \mathrm{C}$ radioactivity; $\mathrm{O}---\mathrm{O},{ }^{3} \mathrm{H}$ radioactivity; $\bullet,{ }^{3} \mathrm{H} /{ }^{14} \mathrm{C}$ ratios

Table 5. Absorbance of the oxidized and dithionite reduced cytochrome oxidase

The protein concentration of the cytochrome oxidase was $0.32 \mathrm{mg} / \mathrm{ml}$ as determined by its radioactivity. The cell path length was $1 \mathrm{~cm}$

\begin{tabular}{ccc}
\hline Maxima & Wavelength & Absorbance \\
\hline \multirow{3}{*}{ Oxidized } & nm & \\
& 280 & 0.700 \\
& 428 & 0.245 \\
Reduced & 605 & 0.025 \\
& 443 & 0.330 \\
& 605 & 0.060 \\
\hline
\end{tabular}

content of $\left[{ }^{3} \mathrm{H}\right]$ leucine, incorporated by the cycloheximide insensitive protein synthesis. The only maximum of the ${ }^{s} \mathrm{H} /{ }^{14} \mathrm{C}$ ratio curve coincides with this polypeptide peak. Another smaller peak of the
${ }^{3} \mathrm{H}$ radioactivity curve is present in the protein band of the molecular weight 30000 . However, this peak, as well as the background in protein stain and radioactivity in the higher molecular weight region, varies from analysis to analysis, whereas the appearance of the ${ }^{3} \mathrm{H}$ peak at the molecular weight 20000 and of the five ${ }^{14} \mathrm{C}$ peaks is fairly constant. Therefore the ${ }^{3} \mathrm{H}$ peak at the molecular weight 30000 and the background might be due to aggregation phenomena.

As shown in Fig.4, mitochondrial membrane protein is composed of at least 20 different polypeptides [21]. At least 4 of them seem to be synthesized by the intrinsic mitochondrial system, as indicated by the maxima of the ${ }^{3} \mathrm{H} /{ }^{14} \mathrm{C}$ ratio curve coinciding with the maxima of the ${ }^{14} \mathrm{C}$ radioactivity curve. Interestingly enough, a maximum of the ${ }^{3} \mathrm{H} /{ }^{14} \mathrm{C}$ ratio curve appears also at the molecular weight 20000 and with almost equal magnitude to the maximum of the ${ }^{3} \mathrm{H} /{ }^{14} \mathrm{C}$ curve of the cytochrome oxidase electrophoresis. 


\section{DISCUSSION}

Due to the choice of a rapidly growing microorganism, mitochondrial membrane protein with high content of radioactivity was obtained by incorporation of labeled amino acids. A small scale preparation of pure cytochrome oxidase from this membrane protein was possible by chromatography on oleyl polymethacrylic acid resin. The protein moiety of this cytochrome oxidase could be disaggregated into five fractions by sodium dodecylsulfate gel electrophoreis. One of these fractions which had the electrophoretic mobility of a polypeptide chain with the molecular weight 20000 , had an exceptionally high content of radioactive leucine, incorporated by the cycloheximide resistent protein synthesis.

Two aspects have to be discussed in more detail. Firstly, is this fraction a polypeptide synthesized by the mitochondrial ribosomes? The specific radioactivity $\left({ }^{3} \mathrm{H} /{ }^{14} \mathrm{C}\right.$ ratio) of this fraction exceeds the corresponding value of the whole membrane protein only three times. This may be due to the high ${ }^{14} \mathrm{C}$ background measured in the gel. On the other hand, if we assume that this fraction is a pure polypeptide, $30 \%$ of the whole membrane protein would be a product of mitochondrial protein synthesis. While one group of authors reported a value in this range [10], others determined values in the range of $15 \%[22,23]$. Hence a higher enrichment of specific radioactivity should be expected of a pure polypeptide of mitochondrial origin. However, we have to consider the possibility, that peptide chains synthesized by the intrinsic mitochondrial system may not be integrated into functional active lipoproteins, when the supply of cytosolic peptides is stopped simultaneously. Polypeptides not integrated into lipoproteins may behave differently during the applied purification procedure. Thus, the enrichment of specific radioactivity $\left({ }^{3} \mathrm{H} /{ }^{14} \mathrm{C}\right.$ ratio) may not be an absolute criterium for estimating the degree of purity of a peptide of mitochondrial origin.

Furthermore, the fractions at the molecular weight of 20000 show almost equal values of the ${ }^{3} \mathrm{H} /{ }^{14} \mathrm{C}$ ratio in the electropherograms of both the whole membrane protein and the purified cytochrome oxidase (Figs. 3 and 4). It is unlikely, that a mixture of equal sized peptide chains would remain unchanged during the preparation procedure. Nevertheless, the possibility cannot be excluded that the electrophoretically separated fractions still are aggregates of even smaller peptide chains which could be preformed in the native membrane. In any case we did not get smaller fractions, either after maleylation of the protein, by addition of urea, by electrophoresis at other $\mathrm{pH}$ values or at higher temperatures. Therefore, we suggest the protein fraction at the molecular weight of 20000 to be a pure polypeptide synthesized by the mitochondrial ribosomes.
Recently the purification of a highly radioactive protein fraction from mitochondrial membrane protein labeled with radioactive amino acids in the presence of cycloheximide was described [38]. After gel electrophoresis in phenol-formic acid medium this fraction appeared as a single protein band at the molecular weight region of about 120000 . As published earlier $[8,9,29,39]$ we also found the label exclusively in protein bands at the molecular weight region of 150000 to $\mathbf{5 5 0 0 0}$ when gel electrophoresis was performed in phenol-formic acid. From our earlyer results we suggest, that some mitochondrial membrane proteins tend to aggregate in phenol-formic acid.

Secondly, is this polypeptide of molecular weight 20000 an integrated part of the cytochrome oxidase? The purity of the cytochrome oxidase preparations is determined most reliably by the ratio of absorbance at $280 \mathrm{~nm}$ (ox.)/443 nm (red.) which amounts to 2.1. This value is in agreement with the value of the crystalline cytochrome oxidase of beaf heart mitochondria [18]. The specific cytochrome $a a_{3}$ content of the cytochrome oxidase preparation was evaluated from its spectral absorbance $\left(\Delta \varepsilon_{605 \mathrm{~nm}}=24 \times 10^{3} \mathrm{M}^{-1}\right.$ $\mathrm{cm}^{-1}$, reduced minus oxidized) and its content of ${ }^{14} \mathrm{C}$ radioactivity to be $4.8 \mu$ moles cytochrome $a a_{3} / g$ protein, or $9.6 \mu$ moles heme $a / g$ protein. This evaluation presupposes, that cytochrome oxidase of Neurospora crassa in the exponential growth phase shows no turnover and shows a leucine content equal to the average of the whole membrane protein. The best preparations reported in the literature all contain 8-11 umoles heme $a / g$ protein $[19,24-26]$, if sufficient corrections are applied for the measurement of heme $a$ content and of the weight of the fat free protein [27].

From these spectroscopic data it follows that the cytochrome oxidase preparation reported in this work fulfils the criteria of purity as established in the literature up to now. The appearance of a polypeptide of mitochondrial origin of an amount comparable to the other components of this preparation seems not to be the matter of contamination.

The conclusion, that at least part of the apoprotein of the cytochrome oxidase is synthesized by the mitochondria themselves, has been drawn also by other authors.

Cytoplasmic inheritant mutants with loss or defect of the mitochondrial protein synthesis $[28,29]$ are reported from Saccharomyces cerevisiae, petitemutant [30], and of Neurospora crassa, mi-mutants [31]. The most remarkable alterations of the phenotypes of these mutants are their complete or partial loss of membrane bound mitochondrial cytochromes. Yeast cells, grown in the presence of chloramphenicol, an inhibitor of the mitochondrial protein synthesis, also show a loss of membrane bound mitochondrial cytochromes. The early suggestions, that these cytochromes are synthesized by the 
mitochondrial system [32] were modified recently, when the necessity of both mitochondrial and cytosolic protein synthesis for the appearance of the cytocrome oxidase during derepression of yeast was revealed $[33,34]$.

Other authors have excluded the participation of the mitochondria in the synthesis of the protein moiety of the cytochrome oxidase. The isolation of a complete apoprotein from mitochondria of the petite-mutant was reported, resembling that of the wild-type by its molecular weight, electrophoretic behaviour and copper content. The conclusion was drawn, that only the deficiency of heme causes the absence of spectroscopically detectable and enzymatically active cytochrome oxidase [35]. In labelling experiments with isolated rat liver mitochondria only a very low label was found in the cytochrome oxidase preparation and was attributed to a contaminating protein [36]. The inhibition of the labelling of the cytochrome oxidase by both cycloheximide and chloramphenicol was reported. However no significant cycloheximide insensitive label was found in the cytochrome oxidase preparation. Therefore, the effect of chloramphenicol was discussed in terms of inhibiting the synthesis of a protein necessary for transport or attachment of the prosthetic group to the cytochrome oxidase apoprotein [37].

In contrast to the latter reports, our finding that the purified cytochrome oxidase is built up of several types of polypeptides and that one of them is highly labeled under the action of cycloheximide, supports the view that part of the apoprotein of the cytochrome oxidase is synthesized by the intrinsic mitochondrial system.

This work was supported by the Deutsche Forschungsgemeinschaft (Schwerpunkt "Biochemie der Morphogenese" und Sonderforschungsbereich 51). The authors are grateful to A. Dittrich for her technical assistance.

\section{REFERENCES}

1. Roodyn, D. B., and Wilkie, D., The Biogenesis of Mitochondria, Methuen, London 1968.

2. Ashwell, M., and Work, T. S., Ann. Revu. Biochem. 39 (1970) 251 .

3. Schatz, G., in Membranes of Mitochondria and Chloroplasts (edited by E. Racker), Van Nostrand Reinhold Company, New York 1970, p. 251.

4. Neupert, W., Brdiczka, D., and Bücher, Th., Biochem. Biophys. Res. Commun. 27 (1967) 488.

5. Beattie, D. S., Basford, R. E., and Koritz, S. B., Biochemistry, 6 (1967) 3099.

6. Neupert, W., and Ludwig, G. D., Eur. J. Biochem. 19 (1971) 523.

7. Beattie, D. S., J. Biol. Chem. 243 (1968) 4027.

8. Sebald, W., Hofstötter, Th., Hacker, D., and Bücher, Th., FEBS Lett. 2 (1969) 177.

9. Sebald, W., Schwab, A.J., and Bücher, Th., FEBS Lett. 4 (1969) 243.

10. Hawley, E. S., and Greenawalt, J.W., J. Biol. Chem. $245(1970) 3574$.
11. Sisler, H.D., and Siegel, M. R., in Antibiotics, Mechanism of Action (edited by D. Gottlieb and P. D. Shaw), Springer Verlag, Berlin-Heideberg-New York 1967, p. 283.

12. Weiß, H., and Bücher, Th., Eur. J. Biochem. $17(1970)$ 561.

13. WeiB, H., von Jagow, G., Klingenberg, M., and Bücher, Th., Eur. J. Biochem. 14 (1970) 75.

14. Smith, L., and Conrad, H., Arch. Biochem. Biophys. 63 (1956) 403.

15. Van Gelder, B. F., Biochim. Biophys. Acta, 118 (1966) 36.

16. Ohnishi, K., J. Biochem. (Tokyo), 59 (1966) 1.

17. Beisenherz, G., Boltze, H.J., Bücher, Th., Czok, R., Garbade, K. H., Meyer-Arendt, E., and Pfleiderer, G., Z. Naturforsch. 8 b (1953) 555 .

18. Yonetani, T., J. Biol. Chem. 236 (1961) 1680.

19. Sekuzu, I., Mizushima, H., and Okunuki, K., Biochim. Biophys. Acta, 85 (1964) 516.

20. Shapiro, A. L., Viñuela, E., and Maizel, J. V., Jr., Biochem. Biophys. Res. Commun. 28 (1967) 815.

21. Schnaitman, C. A., Proc. Nat. Acad. Sci. U.S. A. 63 (1969) 412 .

22. Sebald, W., Schwab, A., and Bücher, Th., in 20. Mos. bacher Colloquium (edited by Th. Bücher and H.Sies), Springer Verlag, Berlin, Heidelberg, New York 1969, p. 728.

23. Schweyen, R., and Kaudewitz, F., Biochem. Biophys. Res. Commun. 38 (1970) 140.

24. Griffiths, D. E., and Wharton, D. C., J. Biol. Chem. 236 (1961) 1850.

25. Wainio, W. W., J. Biol. Chem. 239 (1964) 1402.

26. Okunuki, K., Sekuzu, I., Yonetani, T., and Takemori, S., J. Biochem. (Tokyo), 45 (1958) 847.

27. Lemberg, M. R., Physiol. Rev. 49 (1969) 48.

28. Tuppy, H., and Swetly, P., Biochim. Biophys. Acta, 153 (1988) 293.

29. Sebald, W., Bücher, Th., Olbrich, B., and Kaudewitz, F., FEBS Lett. 1 (1968) 235.

30. Ephrussi, B., and Slonimski, P. P., Nature (London), $176(1955) 1207$.

31. Mitchell, M. B., Mitchell, H. K., and Tissières, A., Proc. Nat. Acad. Sci. U. S. A. 39 (1953) 606.

32. Clark-Walker, G. D., and Linnane, A. W., J. Cell. Biol. 34 (1967) 1.

33. Rouslin, W., and Schatz, G., Biochem. Biophys. Res. Commun. 37 (1969) 1002.

34. Vary, M. J., Stewart, P. R., and Linnane, A. W., Arch. Biochem. Biophys. 141 (1970) 430.

35. Tuppy, H., and Birkmayer, G. D., Eur. J. Biochem. 8 (1969) 237.

36. Beattie, D. S., Patton, G. M., and Stuchell, R. N., J. Biol. Chem. 245 (1970) 2177.

37. Kadenbach, B., in Autonomy of Mitochondria and Chloroplasts (edited by N. K. Boardman, A. W. Linnane, and R. M. Smillie), North Holland, Amsterdam 1971, p. 360.

38. Birkmayer, G. D., Hoppe-Seyler's Z. Physiol. Chem. 352 (1971) 761 .

39. Sebald, W., Birkmayer, G. D., Schwab, A. J., and Weiß, H., in Autonomy of Mitochondria and Chloroplasts (edited by N. K. Boardman, A.W. Linnane, and R. M. Smillie), North Holland, Amsterdam 1971, p. 339.

H. Weiß, W. Sebald, and T. Bücher

Institut für Physiologische Chemie und Physikalische

Biochemie der Universität

BRD-8000 München 15, Goothestraße 33

German Federal Republic 